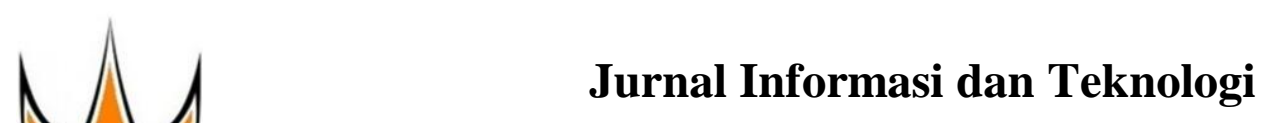

http://www.jidt.org

2021 Vol. $3 \quad$ No. $3 \quad$ Hal: $128-133 \quad$ ISSN: 2714-9730 (electronic)

\title{
Sistem Pakar dalam Mendiagnosis Penyakit Mata dengan Menggunakan Metode Forward Chaining
}

\author{
Budi Permana Putra ${ }^{1 凶}$, Yuhandri Yunus ${ }^{2}$, Sumijan $^{3}$ \\ ${ }^{1,2,3}$ Universitas Putra Indonesia YPTK Padang \\ budipermanaputra96@yahoo.com
}

\begin{abstract}
The eye is one of the organs in the body that has an important role in human life, because the eye is one of the organs that has a function as vision in carrying out every activity. Eye health really needs to be maintained by diligently consulting or having your eyes checked by a doctor so that vision remains clear and there are no eye problems when looking at objects around us. However, eye health is often neglected, so that many various diseases can attack the eye. If not handled properly, diseases that attack the eye can cause visual disturbances and lead to blindness. Therefore, the eye must be kept healthy and kept clean because it is a very important organ of the human body. The purpose of building this expert system is to assist the public in diagnosing eye diseases from the symptoms that are being felt. This expert system will be a way out of eye problems that are suffered by the community, In this way people no longer have trouble going to the doctor. All data and facts to be processed are obtained from an expert, the method used in diagnosing this eye disease is the forward chaining method to apply the rules of the 28 symptoms and 8 diseases described by the expert. The results of the diagnosis using the Forward Chaining method is a very good level of accuracy in determining the type of eye disease that is suffered by the community and can provide early prevention for users who use this expert system.
\end{abstract}

Keywords: Expert System, Forward Chaining, Diagnosis, Eye Diseases, Rule.

\begin{abstract}
Abstrak
Mata adalah salah satu organ tubuh yang mempunyai peran penting di hidup manusia, karena mata salah satu organ yang memiliki fungsi sebagai penglihatan dalam melakukan setiap kegiatan. Kesehatan mata sangat perlu dijaga dengan cara rajin konsultasi atau memeriksakan mata ke dokter agar penglihatan tetap jernih dan tidak ada gangguan pada mata saat melihat objek di sekitar kita. Namun kesehatan mata sering kali terabaikan, sehingga banyak berbagai penyakit yang bisa menyerang mata. Jika tidak ditangani dengan baik, penyakit yang menyerang mata bisa menyebabkan gangguan penglihatan dan menyebabkan kebutaan. Oleh karena itu, mata harus tetap sehat dan dijaga kebersihannya sebab merupakan organ tubuh manusia yang sangat penting. Tujuan dibangunnya sistem pakar ini adalah membantu masyarakat dalam mendiagnosis penyakit mata dari gejala-gejala yang sedang dirasakan. Sistem Pakar ini akan menjadi jalan keluar dari masalah mata yang diderita masyarakat, Dengan cara ini masyarakat tidak lagi mengalami kesulitan untuk pergi ke dokter. Semua data dan fakta yang akan diproses di dapatkan dari seorang Pakar, metode yang digunakan dalam mendiagnosis penyakit mata ini adalah metode forward chaining untuk menerapkan aturan (rule) dari 28 gejala dan 8 penyakit yang jelaskan oleh pakar. Hasil diagnosis menggunakan metode runut maju (Forward Chaining) adalah tingkat akurasi yang sangat baik dalam menentukan jenis penyakit mata yang di derita masyarakat serta dapat memberikan pencegahan dini bagi pengguna yang menggunakan sistem pakar ini.
\end{abstract}

Kata kunci: Sistem Pakar, Forward Chaining, Diagnosa, Penyakit Mata, Aturan.

\section{Pendahuluan}

Perkembangan teknologi komputer pada era sekarang ini mengalami peningkatan yang sangat pesat, dalam skala besar pekerjaan sudah menggunakan teknologi komputer sebagai penunjang, komputer saat ini menjadi alat dalam membantu menyelesaikan masalah yang dihadapi manusia [1]. Saat ini informasi merupakan hal penting, terutama dengan berkembangnya dunia Teknologi Informasi maka masyarakat diberikan kemudahan dalam mendapatkan informasi tersebut [2].

Pelayanan kesehatan di Indonesia menjadi sesuatu hal yang harus ditingkatkan mengingat jumlah penduduk di Indonesia adalah salah satu negara yang paling banyak jumlah penduduknya. Kebanyakan rumah sakit yang ada di Indonesia tidak dapat menyediakan tenaga ahli kesehatan yang cukup sehingga permasalahan kesehatan menjadi salah satu hal yang utama mengingat banyaknya jenis penyakit yang berkembang yang diakibatkan oleh virus [3].

Mata adalah panca indra yang dimiliki manusia sebagai penglihatan, mata juga merupakan alat penting dalam keberlangsungan kegiatan yang dilakukan oleh manusia. Mata dapat mengalami gangguan baik itu yang dapat mengurangi daya penglihatan maupun tidak Menurut hasil survey dari kementerian kesehatan RI pada tahun 2014, penduduk yang menderita masalah penglihatan di provinsi Nusa Tenggara Barat meraih $0,5 \%$ dari jumlah penduduk, hal ini merupakan hasil survei secara keseluruhan dari berbagai macam 
penyakit mata. (Suharningsih, et al, 2019). Masyarakat berbagai macam penyakit, mulai dari infeksi awam kesulitan untuk mengenali jenis penyakit yang asimtomatik dan ringan hingga penyakit parah dan diderita, tanpa pengetahuan yang baik dapat fatal. Penyakit ISPA merupakan penyakit yang harus menyebabkan penanganan yang salah terhadap suatu diperhatikan oleh masyarakat karena bisa menyebabkan penyakit [4].

Sistem pakar merupakan sistem komputer berdasarkan pada pengetahuan terintegrasi ke dalam sistem informasi dasar yang sudah ada, sehingga mempunya kemampuan dalam menyelesaikan suatu masalah di bidang tertentu secara cerdas dan efektif [5]. Sistem ini dirancang untuk memodelkan kemampuan dalam Penelitian lainnya yaitu Sistem Pakar Diagnosa menyelesaikan masalah atau hanya bisa diperoleh Penyakit Gigi Menggunakan Metode Forward dengan bantuan para ahli di bidangnya [6]. Penerapan Chaining. Minimnya pengetahuan kesehatan gigi dan sistem pakar dalam bidang kesehatan atau medis. masih terbatasnya kesadaran masyarakat tentang Untuk memberikan solusi terhadap penyakit-penyakit kesehatan gigi, membuat sebagian masyarakat kita yang memerlukan keahlian seorang dokter spesialis mengesampingkan dalam upaya mencegah atau dalam bidang tersebut [7].

Forward chaining disebut juga suatu penalaran yang dimulai dari bawah ke atas karena penalaran berdasarkan fakta pada level bawah menuju kesimpulan pada level atas yang didasari dengan fakta [8]. teknik penelusuran yang diawali dengan fakta yang sudah diketahui, setelah itu mencocokkan fakta-fakta dengan IF tersebut dari aturan IF-THEN, apabila ada fakta yang cocok dengan IF, maka aturan tersebut dieksekusi. Bila sebuah aturan dieksekusi maka ada fakta yang baru (THEN) dimasukkan kedalam database [9].

Kecerdasan buatan adalah suatu sistem yang berperilaku layaknya manusia, namun tidak dapat menggantikan peran dari seorang pakar. Pengetahuan dalam sistem terus mengalami perkembangan dari waktu ke waktu. Sistem ini menggunakan bebrapa bahasa pemrograman. Tujuan dari kecerdasan buatan yaitu menjadikan mesin menjadi lebih pintar (tujuan utama), memahami arti dari kecerdasan (tujuan ilmiah), dan menjadikan mesin mempunyai banyak manfaat [10].

Penelitian lainnya yaitu Sistem Pakar Diagnosis Penggunaan Softlens dengan Metode Forward Chaining. Softlens atau lensa kontak merupakan suatu alat yang dapat membantu fungsi penglihatan. Seperti yang kita tahu, bahwasanya saat ini banyak masyarakat yang memiliki masalah pada penglihatan mereka. Seperti kelainan mata minus, slindris dan lain-lain. Tujuan penelitian ini yaitu untuk mempermudah proses Untuk mempermudah dalam penyusunan penelitian ini, konsultasi tersebut sehingga dapat meminimalisir Desain kerangka kerja yang jelas perlu dilakukan resiko masalah mata yang mungkin terjadi. Data yang secara bertahap. Kerangka tersebut merepresentasikan dimasukan adalah data atau informasi yang langkah-langkah yang harus diambil untuk diiplementasikan dalam pembangunan sistem pakar ini menyelesaikan masalah. Kerangka kerja penelitian adalah data penyakit dan data gejala penyakit. Hasil yang digunakan dapat dilihat pada Gambar 1 .

dari penelitian yaitu dari pengujian sistem yang telah dilakukan dengan data sample sebanyak 10 pasien, yang dibandingkan dengan hasil diagnosis pakar diperoleh nilai akurasi sistem sebesar $80 \%$ [11].

Penelitian lainnya yaitu Sistem Pakar Diagnosa Penyakit ISPA Berbasis Web Dengan Metode Forward Chaining. Infeksi Saluran Pernapasan Akut (ISPA) adalah penyakit pada saluran pernapasan bagian atas atau bawah. Biasanya menular dan dapat menyebabkan 


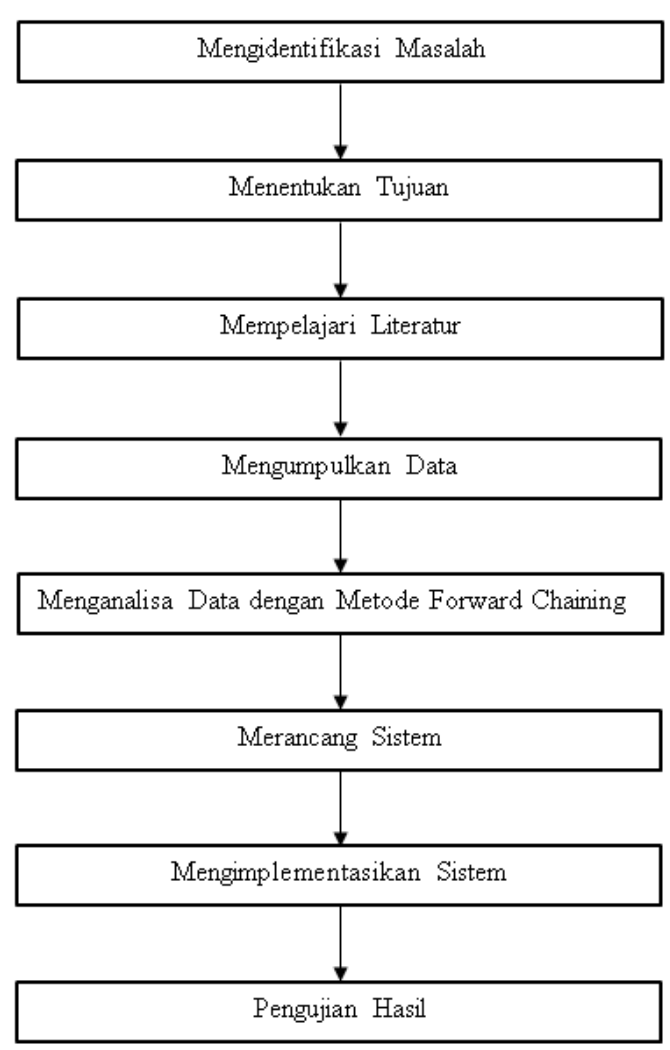

\section{Gambar 1. Kerangka Kerja Penelitian}

Menurut gambar kerangka kerja dapat dijelaskan sebagai berikut:

\subsection{Mengidentifikasi Masalah}

Tahapan identifikasi masalah merupakan langkah awal dalam penelitian ini. Tahap ini penting karena peneliti melakukan perumusan masalah dari masalah-masalah yang ditemukan pada objek penelitian, dan memberikan batasan bagi masalah penelitian, sehingga lebih terkonsentrasi.

\subsection{Menentukan tujuan}

Tujuan penelitian diperlukan agar penelitian ini tidak keluar batas dari tujuan memperoleh hasil terbaik. Tahap ini memperjelas ruang lingkup dan batasan masalah.

\subsection{Mempelajari Literatur}

Untuk mendapatkan landasan teori yang benar dan jelas, maka mempelajari literatur oleh peneliti juga sangat penting. Mempelajari literatur maka penelitian yang dilakukan tidak mengada-ada sehingga penelitian tersebut nantinya dapat diterima di dunia ilmu pengetahuan dan masyarakat umum.

\subsection{Mengumpulkan Data}

Langkah selanjutnya mengumpulkan data untuk mendapatkan sebuah pengetahuan yang digunakan Inference Engine merupakan bagian dari sistem pakar untuk menyelesaikan suatu masalah. Pengumpulan data yang mengandung cara berpikir dan penalaran sistem

dalam penelitian ini dilakukan dengan tahapan yaitu: yang digunakan oleh seorang pakar untuk a. Observasi

Melakukan observasi langsung di lokasi penelitian untuk menemukan permasalahan yang ada secara jelas dan detail.

b. Wawancara

Melakukan wawancara untuk mendapatkan informasi atau data yang lebih detail melalui Tanya Jawab.

c. Identifikasi

Mengidentifikasi masalah dari ruang lingkup masalah, ruang lingkup masalah dalam penelitian ini adalah diagnosis penyakit mata.

d. Studi kepustakaan

Melakukan studi kepustakaan dengan membaca atau memahami buku yang berkaitan dengan judul penelitian agar dapat menunjang dalam proses penganalisaan data dan informasi yang didapat.

\subsection{Merancang Sistem}

Tahap merancang sistem jalankan setelah analisa data diproses. Pada tahap ini melakukan proses perancangan sistem yang terbagi dari struktur data, program, format masukkan (input), dan format keluaran (output).

\subsection{Implementasi Sistem}

Implementasi ini dilakukan untuk membandingkan hasil yang didapatkan dengan analisa secara manual dengan sistem aplikasi yang dibuat menggunakan pemrograman PHP dan database Mysql.

\subsection{Pengujian hasil}

Tahap ini dilakukan pengujian untuk membandingkan hasil dari aplikasi yang dibuat dengan hasil perhitungan manual menggunakan metode Forward Chaining. Tahap ini bertujuan mengetahui kesesuaian antara hasil output dari analisis aplikasi dengan perhitungan secara manual.

\section{Hasil dan Pembahasan}

\subsection{Tahapan Analisa dan Perancangan}

Pada tahapan analisa serta pembahasan akan dijabarkan mengenai rancangan sistem yang akan dibangun untuk kebutuhan perangkat lunak atau aplikasi, yang mana perangkat lunak ini akan menggunakan bahasa pemrograman PHP dan database MySQL.

\subsection{Analisa Sistem}

Sebelum melakukan analisa proses kerja dalam Sistem Pakar, maka dijelaskan arsitektur Sistem Pakar dengan melakukan penyederhanaan pada beberapa komponen, maka arsitektur Sistem Pakar untuk diagnosis penyakit mata didesain sebaik mungkin.

\subsection{Inference Engine}


menyelesaikan masalah dan mencoba menggunakan informasi yang diberikan agar mendapatkan objek yang sama. Algoritma Inference Engine dapat dilihat pada Gambar 2.

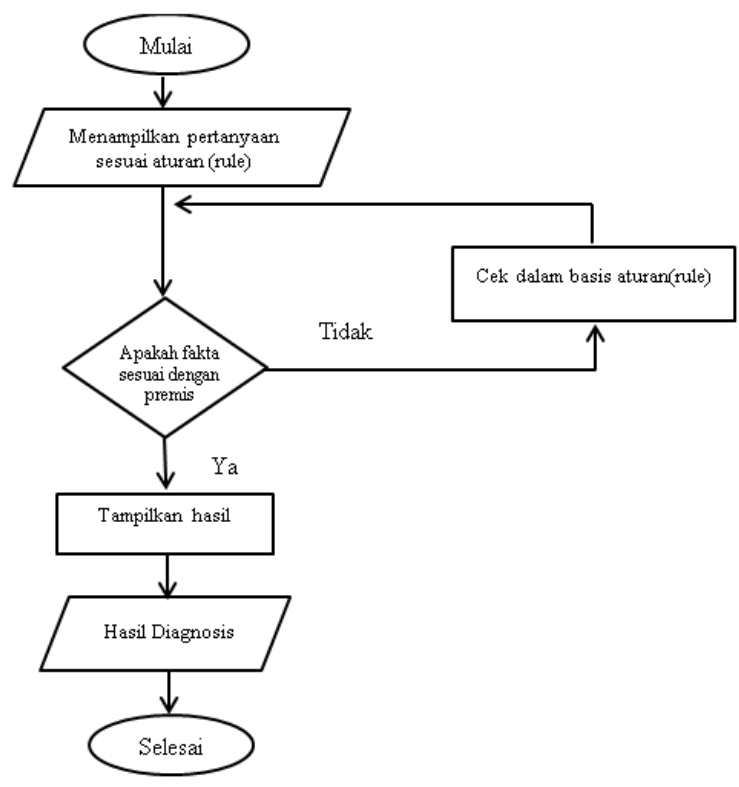

Gambar 2. Algoritma Inference Engine

\subsection{Basis Pengetahuan (Knowledge Base)}

Basis pengetahuan ini berisi pengetahuan-pengetahuan untuk menyelesaikan masalah tertentu,. Basis pengetahuan yang didapat dari Pakar ini mampu meniru atau memperoleh kemampuan Pakar yang diimplementasikan ke dalam sistem atau aplikasi. Pengetahuan (Knowledge) didapat dari wawacara dan observasi langsung dengan pakar, data yang diperoleh dari hasil wawancara langsung dengan Pakar yaitu 8 jenis penyakit mata dan 28 gejala. Untuk jenis penyakit mata dapat dilihat pada Tabel 1.

Tabel 1. Jenis Penyakit

\begin{tabular}{ccl}
\hline No & $\begin{array}{c}\text { Kode } \\
\text { Penyakit }\end{array}$ & \multicolumn{1}{c}{ Jenis Penyakit } \\
\hline 1 & M1 & Katarak \\
2 & M2 & Dry eye (mata kering) \\
3 & M3 & Glaukoma \\
4 & M4 & Keratitis \\
5 & M5 & Myopia \\
6 & M6 & Pterygium \\
7 & M7 & Hypermetropi \\
8 & M8 & Astigmatisma \\
\hline
\end{tabular}

Tabel 2. Gejala

\begin{tabular}{ccl}
\hline No & $\begin{array}{c}\text { Kode } \\
\text { Gejala }\end{array}$ & \multicolumn{1}{c}{ Gejala } \\
\hline 1 & T1 & Penglihatan terasa kabur \\
2 & T2 & Mata berair \\
3 & T3 & Mata bengkak \\
4 & T4 & Mata terasa perih \\
5 & T5 & Mata terasa ada yang mengganjal \\
6 & T6 & Penglihatan silau \\
7 & T7 & Terlihat lingkaran cahaya \\
8 & T8 & Penglihatan objek ganda \\
9 & T9 & Mata berwarna merah \\
10 & T10 & Mata terasa gatal \\
11 & T11 & Mata terasa panas \\
12 & T12 & Sakit kepala \\
13 & T13 & Mata terasa sakit \\
14 & T14 & Mata meradang \\
15 & T15 & Mata nyeri hebat \\
16 & T16 & Mata terasa nyeri \\
17 & T17 & Kelainan pada pupil mata \\
18 & T18 & Mata lelah \\
19 & T19 & Sering mengedipkan mata \\
20 & T20 & Peka terhadap cahaya \\
21 & T21 & Penglihatan dekat terasa kabur \\
22 & T22 & Tekanan bola mata meningkat \\
23 & T23 & Penglihatan objek jauh kurang \\
24 & T24lihat jelas & $\begin{array}{l}\text { Lemak menutupi kornea } \\
\text { Menyipitkan mata untuk melihat }\end{array}$ \\
25 & T25 & benda yang dekat \\
26 & T26 & $\begin{array}{l}\text { Sumber cahaya akan berwarna } \\
\text { pelangi jika melihat cahaya yang }\end{array}$ \\
27 & T27 & $\begin{array}{l}\text { Mata tegang } \\
\text { T28 }\end{array}$ \\
& & Terlihat bayangan garis hitam \\
\hline
\end{tabular}

Berdasarkan data jenis gejala yang didapatkan dari pakar selanjutnya dilakukan penyusunan rule atau aturan. maka didapat hasilnya yang disajikan pada Tabel 3.

Tabel 3. Proses Pelacakan

\begin{tabular}{clc}
\hline No & \multicolumn{1}{c}{ Gejala } & Penyakit \\
\hline 1 & T1, T8, T16, T28 & M1 \\
2 & T5, T20 & M2 \\
3 & T13, T17, T22, T26 & M3 \\
4 & T2, T3, T10, T11, T16 & M4 \\
5 & T12, T18, T19, T23 & M \\
6 & T2, T9, T24 & M6 \\
7 & T12, T21, T25 & M7 \\
8 & T1, T27 & M8 \\
\hline
\end{tabular}

\subsection{Penyajian Aturan (Rules)}

Pada penyajian aturan mengacu dari gejala yang berhubungan dengan penyakit mata, penyajian rule tersebut adalah sebagai berikut: 
Rule 1:

IF Penglihatan kabur is True AND Penglihatan objek ganda is True AND Mata terasa nyeri is True AND Terlihat bayangan garis hitam THEN Penyakit matc Katarak

Rule 2:

IF Mata terasa ada yang mengganjal is True AND Pekc terhadap cahaya THEN Penyakit mata Dry eye (Matc kering)

\section{Rule 3:}

IF Mata terasa sakit is True AND Kelainan pada pupi mata is True AND Tekanan bola mata meningkat i: True AND Sumber cahaya akan berwarna pelangi jika melihat cahaya yang terang THEN Penyakit matc Glaukoma

Rule 4:

IF Mata berair is True AND Mata bengkak is True AND Mata terasa gatal is True AND Mata terasa panas is True AND Mata nyeri THEN Penyakit mata Keratitis

Rule 5:

IF Sakit kepala is True AND Sering mengedipkan mata is True AND Mata lelah is True AND Penglihatan objek jauh kurang terlihat jelas THEN Penyakit mata Miopi

\section{Rule 6:}

IF Mata berair is True AND Mata berwarna merah is True AND Lemak menutupi kornea THEN Penyakit mata Pterygium

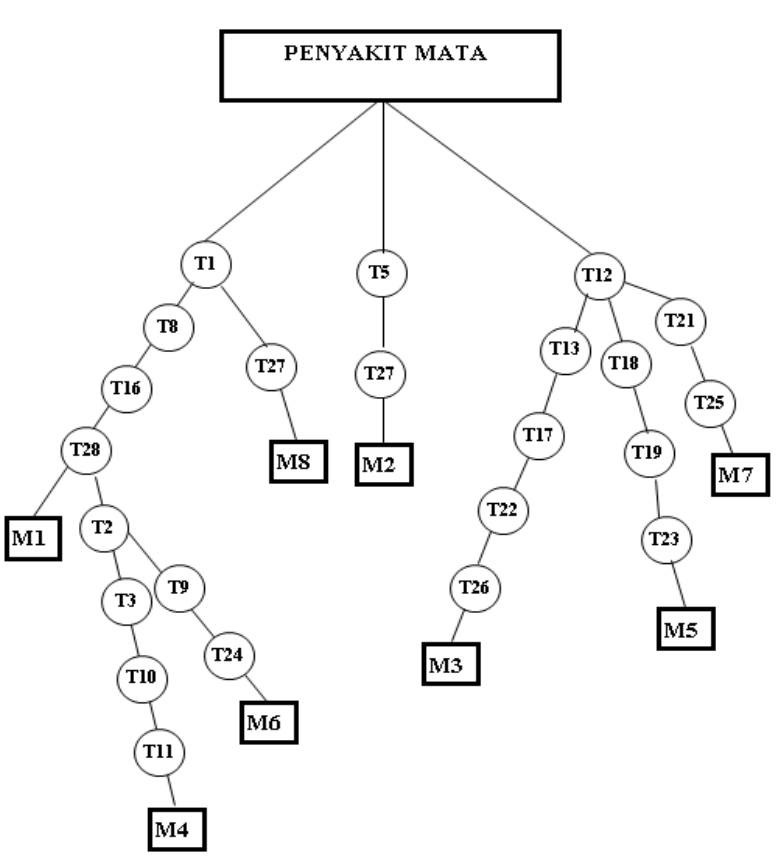

\section{Gambar 3. Pohon Keputusan}

\subsection{Hasil Proses Pelacakan}

Berdasarkan hasil proses pelacakan yang diambil dari beberapa jenis penyakit mata dengan menggunakan metode Forward Chaining maka didapatkan hasil keputusan yang disajikan pada Tabel 4.

\section{Rule 7:}

IF Sakit kepala is True AND Penglihatan dekat terasa kabur is True AND Menyipitkan mata untuk melihat benda yang dekat THEN Penyakit mata Hypermetropi

Rule 8:

IF Penglihatan kabur is True AND Mata tegang THEN Penyakit mata Astigmatisma

Tabel 4. Hasil Proses Pelacakan

\begin{tabular}{|c|c|c|c|}
\hline No & Penyakit & Rule & $\begin{array}{c}\text { Kode } \\
\text { Penyakit }\end{array}$ \\
\hline 1. & Katarak & $\begin{array}{l}I F \text { T1 } A N D \text { T8 AND } \\
\text { T16 AND T28 THEN } \\
\text { M1 }\end{array}$ & M1 \\
\hline 2. & Dry eye & $\begin{array}{l}\text { IF T5 AND } \mathrm{T} 20 \\
\text { THEN M2 }\end{array}$ & M2 \\
\hline 3. & Myopia & $\begin{array}{lll}I F \quad \mathrm{~T} 12 & A N D & \mathrm{~T} 18 \\
\text { AND } \mathrm{T} 19 & A N D & \mathrm{~T} 23 \\
\text { THEN M5 }\end{array}$ & M5 \\
\hline
\end{tabular}

\subsection{Pohon Keputusan}

Setelah mendapatkan gejala penyakit dari data yang telah ada, maka tahap berikutnya adalah membuat Berdasarkan sampel kasus pada Tabel 4 yang melalui pohon keputusan untuk membantu dalam pelacakan, dapat di hasilkan diagnosis dari penyakit mengklasifikasikan penyakit berdasarkan gejala-gejala mata adalah Katarak (M1), Dry eye (M2), Myopia yang diperoleh. Adapun pohon keputusan dari sistem (M5).

pakar pada Gambar 3.

\section{Kesimpulan}

Dengan penerapan Sistem Pakar diagnosa penyakit mata, dapat membantu masyarakat yang memerlukan informasi dan ingin mengetahui penyakit mata dari gejala yang sedang dirasakan dengan melakukan diagnosis awal secara online dimanapun secara cepat dan akurat karena sudah berbasis website. Dengan memanfaatkan database MySql, sistem pakar yang dibangun ini dapat menyimpan representasi pengetahuan seorang pakar dari penalaran (Forward Chaining) serta dapat menyimpan data-data konsultasi 
yang dulu telah dilakukan supaya bisa dijadikan sebagai pedoman untuk konsultasi berikutnya.

\section{Daftar Rujukan}

[1] Widodo, A. E., Suleman., Ardiansyah, A., Pratmanto, D., Aji, S., \& Savitri, D. (2020). Sistem Pakar Diagnosa penyakit gigi menggunakan Metode Forward Chaining. Jurnal Sains dan Manajemen. $\quad 8(1), \quad 111-120 . \quad$ DOI: https://doi.org/10.31294/evolusi.v8i1.7479 .

[2] Ritonga, M. R., Solikhun, S., Lubis, M. R., \& Windarto, A. P. (2018). Sistem Pakar Diagnosa Gejala Awal Penyakit Akibat Virus Pada Anak Berbasis Mobile dengan Metode Forward Chaining. Jurnal Nasional Informatika dan Teknologi Jaringan. 2(2). DOI: https://doi.org/10.30743/infotekjar.v2i2.298 .

[3] Andriyanto., Sanni, M. I., Dody. (2018). Sistem Pakar Diagnosa Penyakit Infeksi Saluran Pernapasan Akut Menggunakan Metode Forward Chaining. Journal Cices, 4(2). DOI: https://doi.org/10.33050/cices.v4i2.504.

[4] Yansyah, I. R., \& Sumijan. (2021). Sistem Pakar Metode Forward Chaining untuk Mengukur Keparahan Penyakit Gigi dan Mulut. Jurnal Sistim Informasi dan Teknologi. 3(2). 41-47. DOI: https://doi.org/10.37034/jsisfotek.v3i2.103

[5] Sari, M., Defit, S. \& Nurcahyo, G. W. (2020). Sistem Pakar Deteksi Penyakit pada Anak Menggunakan Metode Forward Chaining. Jurnal Sistim Informasi dan Teknologi. 2(4). 130-135. DOI: https://doi.org/10.37034/jsisfotek.v2i4.114.

[6] Wisky, I. A., \& Akhiyar, D. (2019). Sistem Pakar Untuk Mendiagnosa Penyakit Tulang Berbasis Web Menggunakan
Metode Forward Chaining. Jurnal Sains dan Teknologi. 19(1). DOI: http://dx.doi.org/10.36275/stsp.v19i1.126 .

[7] Nugroho, F. A. (2018). Perancangan Sistem Pakar Diagnosa Penyakit Jantung dengan Metode Forward Chaining. Jurnal Informatika Universitas Pamulang. 3(2). DOI: http://dx.doi.org/10.32493/informatika.v3i2.1431 .

8] Yenila, F., \& Wiyandra, Y. (2019). Sistem Pakar Ginekologi dengan Metode Forward Chaining dan Certainty Factor. Journal of Information Systems and Informatics Engineering, 3(2). DOI: http://doi.org/10.35145/joisie.v3i2.480 .

9] Suminten., \& Rani. (2018). Sistem Pakar Diagnosa Kerusakan Laptop Menggunakan Metode Forward Chaining. JURNAL RESTI. 2(3). 604-610. DOI: http://doi.org/10.29207/resti.v2i3.468 .

[10] Kurnia, R. P., Yuhandri., Sumijan. (2018). Sistem Pakar Diagnosis Penggunaan Softlens dengan Metode Forward Chaining. Jurnal Sains, Teknologi dan Industri. 16(1), 66-71. DOI: http://doi.org/10.24014/sitekin.v16i1.5826 .

11] Ramadhani, T. F., Fitri, I., \& Handayani, E. T. E. (2020). Sistem Pakar Diagnosa Penyakit ISPA Berbasis Web dengan Metode Forward Chaining. JOINTECS. 5(2), 81-90. DOI: https://doi.org/10.31328/jointecs.v5i2.1243.

[12] Munaiseche, C. P. C., Kaparang, D. R., \& Rompas, P. T. D. (2018). An Expert System for Diagnosing Eye Diseases using Forward Chaining Method. IOP Conference Series: Materials Science and Engineering. 306(1). IOP Publishing. DOI: http://doi.org/10.1088/1757-899X/306/1/012023 